\title{
Editorial
}

\section{Should we Measure Arterial Stiffness in Hypertensive Women}

\author{
C. Bhaktavatsal Reddy ${ }^{1}$ \\ ${ }^{1}$ Department of Cardiology, Apollo Hospitals, Nellore, India \\ Ind J Car Dis Wom:2020;5:305-307
}

\section{Introduction}

Hypertension is identified as the world's leading risk factor for cardiovascular morbidity and mortality ${ }^{1}$ Hypertension is widely seen in men; however, compared with younger women, it is more prevalent among women than in older men. ${ }^{2}$ Hypertension is associated with decreased arterial distensibility or increased arterial stiffness. This is partly attributed to high-pressure blood flow, which stretches the vessel wall, inducing endothelial dysfunction. Nitric oxide (NO) released from healthy endothelium is responsible for maintaining resting distensibility. ${ }^{3}$ Age, obesity, acute and chronic smoking, diabetes, hypertension, end-stage renal disease and hypercholesterolemia, labeled as the potential cardiovascular disease risk factors, often remain the same for arterial stiffness. ${ }^{4}$ As blood passes through these rigid arteries, higher amplitude pressure waves are produced during forward motion, and these waves return early as reflective waves, causing vasculature damage to heavily perfused organs such as myocardium, kidney, and brain.

Pulse wave velocity (PWV) is the forward pressure wave speed and an arterial stiffness marker. PWV can be obtained from carotid and femoral waveforms ${ }^{5}$ or brachial tibial waveforms. ${ }^{6,7}$ Studies have shown that cardiovascular predictions and all-cause death can be made even in noncardiovascular subjects based on carotid femoral (Cf) PWV values. ${ }^{8,9}$ Arterial stiffness risk can be classified as normal, mild, moderate, and severe, based on the normal values which ranges from 5 to $>15 \mathrm{~m} / \mathrm{s}^{10-13}$ In $2007^{14}$ ESH/ESC specified the threshold value of Cf-PWV as $12 \mathrm{~m} / \mathrm{s}$. Systemic studies focusing on these guidelines have shown that a $1 \mathrm{~m} / \mathrm{s}$ increase in Cf-PWV is related to $10 \%$ cardiovascular accident risk. ${ }^{15}$

In a study, Diabetes Risk Profiler, a noninvasive blood pressure curve device, was used to evaluate PWV in women with hypertension. Increase in PWV was found to correlate with elevated blood pressure. ${ }^{16,17}$ Patients have significantly higher blood pressure and PWV compared with the controls. The variations in PWV values across varying degrees of

\author{
Address for correspondence \\ C. Bhaktavatsal Reddy, MD, DM, \\ Department of Cardiology, Apollo \\ Hospitals, Nellore, 524002, India \\ (e-mail: bhakthadm@yahoo.co.in)
}

hypertension, however, were not significant. That is due to the fact that most of patients were using vasodilators. Duration of antihypertensive use, location of PWV assessment, blood pressure, heart rate smoking, alcohol, and salty diet intake prior to PWV measurement should be considered as confounding factors when assessing differences in PWV values across these groups.

Hypertension, a major cardiovascular disease risk factor, can contribute to increased oxidative stress, microvascular inflammation, and endothelial damage. During hypertension, elastic fibers become compromised and damaged, resulting in decreased arterial wall stiffness. ${ }^{18}$ Hypertension duration is substantially correlated with artery stiffening due to excessive oxidative load and prolonged strain, resulting in gradual vascular remodeling and loss of artery elasticity.

In women under 60 years of age, PWV is smaller than in males, but values increase sharply after menopause. ${ }^{19}$ In postmenopausal women, endogenous vasodilatory estrogen ${ }^{20}$ depletion leads to increased arterial rigidity. ${ }^{21}$ Increased arterial stiffness in women results in poor hypertension control, weaker diastolic activity, impaired cardiac-arterial coupling, and left ventricular remodeling, all related to adverse cardiovascular effects. ${ }^{22}$

Interventions should aim to alter modifiable risk factors and prevent early development of increased arterial rigidity. Aerobic exercise, ${ }^{23}$ intake of moderate alcohol, ${ }^{24}$ and diet rich in flavonoids ${ }^{25}$ and low in salt ${ }^{26}$ have been shown to enhance artery compliance despite decreased blood pressure. By lowering blood pressure, vasodilators such as nitroglycerin, ${ }^{27}$ drugs that inhibit renin angiotensin, ${ }^{28-31}$ and calcium channel blockers ${ }^{32}$ have shown increased compliance. Among vasodilators, drugs inhibiting renin-angiotensin-aldosterone pathways tend to have superior effect than others in decreasing arterial stiffness. ${ }^{33}$ Statins, ${ }^{34}$ by restoring endothelial functionality, demonstrated positive impact on arterial stiffness. Nebivolol, a NO donor $\beta$-blocker, has shown to reduce PWV independent of blood pressure and

C2020. Women in Cardiology and Related Sciences.

This is an open access article published by Thieme under the terms of the Creative Commons Attribution-NonDerivative-NonCommercial-License, permitting copying and reproduction so long as the original work is given appropriate credit. Contents may not be used for commercial purposes, or adapted, remixed, transformed or built upon. (https://creativecommons.org/licenses/by-nc-nd/4.0/).

Thieme Medical and Scientific Publishers Pvt. Ltd. A-12, 2nd Floor, Sector 2, Noida-201301 UP, India 
heart rate-lowering effects. ${ }^{35}$ By its anti-inflammatory effect, endothelin-A antagonists ${ }^{36}$ and acetylsalicylic acid (aspirin) improved arterial stiffness. Blood glucose-lowering drugs like glitazones and metformin ${ }^{37,38}$ have shown improved arterial rigidity through multiple mechanisms. A research found that hormone therapy (HT) administration reversed arterial stiffness, ${ }^{39}$ but exacerbated after HT discontinuation. ${ }^{40}$

\section{Conclusion}

Hypertensive women experience higher pulse pressure and stiffness. In diagnosing early cardiovascular disease in hypertension, evaluation of arterial stiffness, in addition to blood pressure, is essential. Treatments to alter cardiovascular risk factors, lower blood pressure, and enhance endothelial reflection may be useful in preventing further vascular disease progression in hypertension.

\section{Conflicts of Interest}

None declared.

\section{References}

1 Williams B, Mancia G, Spiering W, et al. [2018 ESC/ESH Guidelines for the management of arterial hypertension]. Kardiol Pol 2019;77(2):71-159

2 Go AS, Mozaffarian D, Roger VL, et al; American Heart Association Statistics Committee and Stroke Statistics Subcommittee. Executive summary: heart disease and stroke statistics-2014 update: a report from the American Heart Association. Circulation 2014;129(3):399-410

3 Kinlay S, Creager MA, Fukumoto M, et al. Endothelium-derived nitric oxide regulates arterial elasticity in human arteries in vivo. Hypertension 2001;38(5):1049-1053

4 Mitchell GF, Guo C-Y, Benjamin EJ, et al. Cross-sectional correlates of increased aortic stiffness in the community: the Framingham Heart Study. Circulation 2007;115(20):2628-2636

5 Townsend RR, Wilkinson IB, Schiffrin EL, et al; American Heart Association Council on Hypertension. Recommendations for improving and standardizing vascular research on arterial stiffness: a scientific statement from the American Heart Association. Hypertension 2015;66(3):698-722

6 Munakata M. Brachial-ankle pulse wave velocity in the measurement of arterial stiffness: recent evidence and clinical applications. Curr Hypertens Rev 2014;10(1):49-57

7 Coutinho T. Arterial stiffness and its clinical implications in women. Can J Cardiol 2014;30(7):756-764

8 Ben-Shlomo Y, Spears M, Boustred C, et al. Aortic pulse wave velocity improves cardiovascular event prediction: an individual participant meta-analysis of prospective observational data from 17,635 subjects. J Am Coll Cardiol 2014;63(7):636-646

9 Vlachopoulos C, Aznaouridis K, Stefanadis C. Prediction of cardiovascular events and all-cause mortality with arterial stiffness: a systematic review and meta-analysis. J Am Coll Cardiol 2010;55(13):1318-27

10 Cohn JN, Finkelstein S, McVeigh G, et al. Noninvasive pulse wave analysis for the early detection of vascular disease. Hypertension 1995;26(3):503-508

11 Boutouyrie P, Tropeano AI, Asmar R, et al. Aortic stiffness is an independent predictor of primary coronary events in hypertensive patients: a longitudinal study. Hypertension 2002;39(1):10-15

12 Luft FC. Molecular mechanisms of arterial stiffness: new insights. J Am Soc Hypertens 2012;6(6):436-438
13 Willum-Hansen $\mathrm{T}$, Staessen JA, Torp-Pedersen C, et al. Prognostic value of aortic pulse wave velocity as index of arterial stiffness in the general population. Circulation 2006;113(5):664-670

14 Mancia G, De Backer G, Dominiczak A, et al; The task force for the management of arterial hypertension of the European Society of HypertensionThe task force for the management of arterial hypertension of the European Society of Cardiology. 2007 Guidelines for the management of arterial hypertension: The Task Force for the Management of Arterial Hypertension of the European Society of Hypertension (ESH) and of the European Society of Cardiology (ESC) Eur Heart J 2007;28(12):1462-1536

15 Vlachopoulos C, Aznaouridis K, Stefanadis C. Prediction of cardiovascular events and all-cause mortality with arterial stiffness: a systematic review and meta-analysis. J Am Coll Cardiol 2010;55(13):1318-1327

16 Nethi A, Kumar B R, Fatima F, Pauniker VM, M AK, Taranikanti M. Arterial stiffness as a measure of vascular dysfunction in hypertensive women. Ind J Car Dis Wom 2020;2:87-170

17 Ni Y, Wang H, Hu D, Zhang W. The relationship between pulse wave velocity and pulse pressure in Chinese patients with essential hypertension. Hypertens Res 2003;26(11):871-874

18 Greenwald SE. Ageing of the conduit arteries. J Pathol 2007;211(2):157-172

19 Gatzka CD, Kingwell BA, Cameron JD, et al; ANBO2 investigators. Australian Comparative Outcome Trial of Angiotensin-Converting Enzyme Inhibitor- and Diuretic-Based Treatment of Hypertension in the Elderly. Gender differences in the timing of arterial wave reflection beyond differences in body height. J Hypertens 2001;19(12):2197-2203

20 Nakamura Y, Suzuki T, Sasano H. Estrogen actions and in situ synthesis in human vascular smooth muscle cells and their correlation with atherosclerosis. J Steroid Biochem Mol Biol 2005;93(2-5):263-268

21 Bowling M, Oparil S, Hage F, Hilgers RH, Xing D. Sex hormones and vascular function. In: Raghavendra D, ed. Sex Hormones. Rijeka: InTec; 2012:1-30

22 Mitchell GF, Parise H, Benjamin EJ, et al. Changes in arterial stiffness and wave reflection with advancing age in healthy men and women: the Framingham Heart Study. Hypertension 2004;43(6):1239-1245

23 Miyachi M, Donato AJ, Yamamoto K, et al. Greater age-related reductions in central arterial compliance in resistance-trained men. Hypertension 2003;41(1):130-135

24 Sierksma A, Lebrun CEI, van der Schouw YT, et al. Alcohol consumption in relation to aortic stiffness and aortic wave reflections: a cross-sectional study in healthy postmenopausal women. Arterioscler Thromb Vasc Biol 2004;24(2):342-348

25 Teede HJ, McGrath BP, DeSilva L, Cehun M, Fassoulakis A, Nestel PJ. Isoflavones reduce arterial stiffness: a placebo-controlled study in men and postmenopausal women. Arterioscler Thromb Vasc Biol 2003;23(6):1066-1071

26 Safar ME, Temmar M, Kakou A, Lacolley P, Thornton SN. Sodium intake and vascular stiffness in hypertension. Hypertension 2009;54(2):203-209

27 Koumaras C, Tzimou M, Stavrinou E, et al. Role of antihypertensive drugs in arterial 'de-stiffening' and central pulsatile hemodynamics. Am J Cardiovasc Drugs 2012;12(3):143-156

28 Shahin Y, Khan JA, Chetter I. Angiotensin converting enzyme inhibitors effect on arterial stiffness and wave reflections: a meta-analysis and meta-regression of randomised controlled trials. Atherosclerosis 2012;221(1):18-33

29 Mahmud A, Feely J. Favourable effects on arterial wave reflection and pulse pressure amplification of adding angiotensin II receptor blockade in resistant hypertension. J Hum Hypertens 2000;14(9):541-546 
30 Frimodt-Møller M, Kamper A-L, Strandgaard S, Kreiner S, Nielsen AH. Beneficial effects on arterial stiffness and pulse-wave reflection of combined enalapril and candesartan in chronic kidney disease-a randomized trial. PLoS One 2012;7(7):e41757

31 Mitchell GF, Lacourcière Y, Arnold JMO, Dunlap ME, Conlin PR, Izzo JL Jr. Changes in aortic stiffness and augmentation index after acute converting enzyme or vasopeptidase inhibition. Hypertension 2005;46(5):1111-1117

32 Williams B, Lacy PS, Thom SM, et al; CAFE Investigators; Anglo-Scandinavian Cardiac Outcomes Trial Investigators; CAFE Steering Committee and Writing Committee. Differential impact of blood pressure-lowering drugs on central aortic pressure and clinical outcomes: principal results of the Conduit Artery Function Evaluation (CAFE) study. Circulation 2006;113(9):1213-1225

33 Gismondi RA, Oigman W, Neves MF. Antihypertensive agents and arterial stiffness. J Thorac Dis 2016;8(7):1386-1387

34 Mihos CG, Pineda AM, Santana O. Cardiovascular effects of statins, beyond lipid-lowering properties. Pharmacol Res 2014;88:12-19

35 Agabiti-Rosei E, Porteri E, Rizzoni D. Arterial stiffness, hypertension, and rational use of nebivolol. Vasc Health Risk Manag 2009;5(1):353-360
36 Nar G, Soylu K, Akcay M, et al. Evaluation of the relationship between arterial blood pressure, aortic stiffness and serum endothelin-1 levels in patients with essential hypertension. Clin Exp Hypertens 2013;35(8):589-594

37 Agarwal N, Rice SPL, Bolusani H, et al. Metformin reduces arterial stiffness and improves endothelial function in young women with polycystic ovary syndrome: a randomized, placebo-controlled, crossover trial. J Clin Endocrinol Metab 2010;95(2):722-730

38 Kaya MG, Calapkorur B, Karaca Z, et al. The effects of treatment with drospirenone/ethinyl oestradiol alone or in combination with metformin on elastic properties of aorta in women with polycystic ovary syndrome. Clin Endocrinol (Oxf) 2012;77(6):885-892

39 Kawecka-Jaszcz K, Czarnecka D, Olszanecka A, Rajzer M, Jankowski P. The effect of hormone replacement therapy on arterial blood pressure and vascular compliance in postmenopausal women with arterial hypertension. J Hum Hypertens 2002;16(7):509-516

40 Waddell TK, Rajkumar C, Cameron JD, Jennings GL, Dart AM, Kingwell BA. Withdrawal of hormonal therapy for 4 weeks decreases arterial compliance in postmenopausal women. J Hypertens 1999;17(3):413-418 